\title{
Automation, Al and the Future of Work in India
}

\author{
Anita Hammer, University of Essex, UK \\ Suparna Karmakar, Kolkata Chamber of Commerce, India
}

Employee Relations (accepted for publication on 30 March 2021)

\section{Purpose}

This research contributes to current debates on automation and the future of work, a much-hyped but under researched area, in emerging economies through a particular focus on India. It assesses the national strategy on Artificial Intelligence and explores the impact of automation on the Indian labour market, work and employment to inform policy.

\section{Methodology}

The article critically assesses the National Strategy on Al, promulgated by NITI Aayog (a national policy think tank), supported by the government of India and top industry associations, through a sectoral analysis. The key dimensions of the national strategy are examined against scholarship on the political economy of work in India to better understand the possible impact of automation on work.

\section{Findings}

The study shows that technology is not free from the wider dynamics that surround the world of work. The adoption of new technologies is likely to occur in niches in the manufacturing and services sectors, while its impact on employment and the labour market more broadly, and in addressing societal inequalities will be limited. The national strategy, however, does not take into account the nature of capital accumulation and structural inequalities that stem from a large informal economy and surplus labour context with limited upskilling opportunities. This raises doubts about the effectiveness of the current policy.

\section{Research Implications}

The critical assessment of new technologies and work has two implications: first, it underscores the need for situated analyses of social and material relations of work in formulating and assessing strategies and policies; second, it highlights the necessity of qualitative workplace studies that examine the relationship between technology and the future of work. 


\section{Practical implications}

The article assesses an influential state policy in a key aspect of future of work - automation.

\section{Social implications}

The policy assessed in this study would have significant social and economic outcomes for labour, work and employment in India. The study highlights the limitations of the state policy in addressing key labour market dimensions and work and employment relations in its formulation and implementation.

\section{Originality and Value}

This study is the first to examine the impact of automation on work and employment in India. It provides a critical intervention in current debates on future of work from the point of view of an important emerging economy defined by labour surplus and a large informal economy.

\section{Introduction}

The transformational effects of emerging new technologies, such as automation and Artificial Intelligence (Al), are key points of discussion in debates on the future of work. Optimistic narratives about the potential for progress and prosperity from the Fourth Industrial Revolution (4IR) (Schwab, 2015) are counterpointed by gloomy predictions of a bleak future, where robots and automated processes lead to mass casualization, surveillance and control (Graham et al., 2017; Fuchs, 2016; Ford, 2015). These extreme positions are, however, both tempered by academic scholarship, which emphasises that these technologies are most likely to impact on the nature and quality of work, rather than replacing it (Thompson and Briken, 2017). Automation is not a new phenomenon, and fears about technological transformation of the workplace and its effects on employment date back a long time (Braverman, 1974). Research on the scope of the impact of new technologies is still emerging, and is even rarer in emerging and developing economies (Lima et al., 2021 for Brazil).

It is important to situate global narratives in the specific contexts of developing and emerging economies, because the impact of technology on the future of work will be shaped by a complex interplay of social and material relations. In labour-abundant economies such as India, the effects of emerging technologies could potentially be dramatic and pose a challenge for development paradigms. India has for a long time struggled with structural inequalities and poverty, a predominance of informal work and self-employment, processes decentring work from the workplace, a withdrawal of the state from social provisioning, and challenges for workers' collective 
organisation. At the same time, India has niche expertise in Information Technology, and young graduates and mid-level professionals appear likely to benefit from the Al revolution (NITI Aayog, 2018). Tensions over inequality - aggravated by fears that technological innovations will undermine job opportunities and security - dominate the discourse. An assessment of the potential of new technologies, extent of their adoption and impact can provide critical insights into the future of work in India, and other similar economies, and thus assist in devising effective policy interventions.

This article contributes to current debates by an assessment of the impact of automation and $\mathrm{Al}$ on work and employment in India, probing the role of policy. Given that research on this subject in the Indian context is scant, it critically assesses the National Strategy on Al articulated in the NITI Aayog report, which is supported by the Government of India and by top industry organisations, NASSCOM and $\mathrm{FICCl}$, through a sectoral analysis. This strategy is examined against scholarship on the political economy of work in India (for example, Hammer, 2019; Barnes, 2018; Raj and Sen, 2016; Breman, 2010). The key argument is that the National Strategy on Al does not account for the nature of capital accumulation and the labour market in India, where a large informal economy is central to how work and employment is organised, and skills are developed and deployed. The article argues that, for any policy intervention to succeed, it is necessary to acknowledge and address this reality, and thereby raises doubts about the effectiveness of the state's strategy on automation and $\mathrm{Al}$ through a sectoral analysis of the impact of automation on work. This understanding has farreaching implications, because a large portion of the world populace labours in informal and precarious work that is insecure, poorly paid and unprotected. Informal labour accounts for 85.8 per cent of total employment in Africa, 71.4 per cent in Asia and the Pacific, 68.6 per cent in the Middle East and 53.8 per cent in the Americas, for a total of 69.6 per cent in all developing economies. In addition, the extension of processes of precarisation across the whole Global North makes the level 61.2 per cent globally (ILO 2018a).

The article is structured as follows. The next section reviews key debates on automation, Al and 4IR, and situates India in the debate. Section three outlines and assesses main aspects of the national strategy on automation and $\mathrm{Al}$ and its impact on work in key sectors. Conclusions are drawn in the final section.

\section{Automation, $\mathrm{Al}$ and Work: Context and Debates}

In global narratives of the future of work, the technological shift referred to as the Fourth Industrial Revolution (Schwab, 2015) is supposedly leading to a dramatic rise in industrial as well as servicesector automation, which is changing labour markets and sometimes replacing skilled labour. Accelerating innovation and new technologies are creating new occupations, new industries, and 
new ways of working. The scope, velocity, and systemic impact of these recent developments have given rise to widespread fears about the future of work and employment, leading to the elimination of jobs and the disappearance of many current occupations (Hirschi, 2017; Ford, 2015). Some argue for the need to devise new mechanisms to either slow down the effects of automation or compensate for lost income in the form of Basic Income programmes (Davala et al., 2015; Standing, 2017).

Despite the hype around developments in technology, the evidence suggests that the spread of emerging technology is less significant than often assumed, and, in terms of the generation of profit, has so far had only a marginal effect (World Development Report, 2019). The widely popularised report by Frey and Osborne (2017), which estimated that about 50 per cent of total US employment is at risk of being automated, was criticised on similar grounds. The fear of large-scale loss of jobs to technology was argued to be unfounded, since jobs consist of many tasks, among which several might not be easily automatable, in particular non-repetitive and unstructured tasks; automation is unlikely to eliminate entire occupations (Autor, 2015). In reality, platform companies bring some elements of a new business model and new ways of organising work, and as such present challenges for policy makers. Platforms do not, however, represent a fundamental change from familiar patterns of corporate activity within a capitalist economy (Forde et al., 2017).

Scholarship, such as labour process analyses, has shown that automation and digitisation do not lead to the disappearance of work (Braverman, 1974; Briken et al., 2017). Technological change and adaptation of it seldom follows a linear path, and often suffers significant time-lags between development and mass adoption, as exemplified by solar energy, the internet and algorithmic computing in the twentieth century, and electric vehicles and autonomous transport systems in more recent times. How technologies develop, the forms they take and their manner of implementation are shaped by wider capitalist social relations, including the agency of employers, state actors, workers and representative bodies. Just as different forms of capital have different imperatives and orientations that alter their relationship with technological development, workers' collective agency also guides its implementation. New technologies of work are enmeshed in managerial systems and are shaped by different, often conflicting, necessities. This results in variations in outcomes at the workplace, as suggested by research. For example, Schorpf et al. (2017) describe new forms of control and dissent in crowdsourcing platforms, and Movitz and Alvin (2017) argue that individualised employment relationships create intragroup and intergroup conflicts with limited scope for collectivisation. However, others suggest that new technology and digitisation could empower workers and create a new sphere of action, while acknowledging a general reduction in autonomy and increased control over workers (Boes et al., 2017). 
The findings on the scope and disruptive potential of new technologies for work and employment remain mixed and disputed, with limited research. Nevertheless, a visible outcome of technological progress in the US and European labour markets in recent decades has been the increasing polarisation of the labour market (Autor and Dorn, 2013; Goos et al., 2009). In particular, the demand for highly skilled workers has increased, while the demand for workers with less education and lower skills has declined. Because the range of tasks that can be automated is expanding rapidly, job polarisation is expected to also continue in higher-skilled jobs and tasks (Autor, 2015; see Lima et al., 2021 for Brazil). Not surprisingly, the pressure to increase skills through lifelong learning and continued education has grown.

Another major trend has been considerable employment creation in the gig economy, which includes crowd-work and work-on-demand via apps, even though their relative numbers remain small (De Stefano, 2016; Forde et al., 2017). In India, around 1.3 million migrant workers joined the gig economy in 2018, 60 per cent more than in the previous six-month period (TeamLease Services, 2018). For context, in the last decade approximately 4.75 million people joined the labour force annually in India. What is significant is that an estimated 56 per cent of the new employment generated by the gig economy is in companies that remain mostly unregulated, where job security and benefits are minimal. Food delivery apps Zomato and Swiggy, and cab aggregators Uber and Ola lead this industry. McKinsey Global Institute (2016) found that gig-activities were still predominantly offered through traditional supply channels as opposed to e-platforms; only 15 per cent of all independent workers surveyed reported using a digital platform for their work.

\section{Implications for Development Models and Equality}

Despite the likely benefits of technology, several key challenges lie ahead, such as those relating to its potential to exacerbate inequality and to disrupt labour markets. Among the salient considerations in the discussion on the future of work, some are of greater relevant in the context of emerging economies like India, such as the role emerging technologies will play in the development models, the reshaping of skills by technological and development changes, and the implications of these trends for social equity.

First, technology is blurring the traditional boundaries between the firm and labour, as is evident in platform marketplaces, with ambiguous results. Using digital technologies, entrepreneurs are creating global platform-based businesses that differ from the traditional input-output production processes. This is relevant for developing countries aiming to leapfrog some points along the development spectrum, since digital platforms can help even traditional companies to scale-up faster and at much lower cost. On the other hand, the rapid transmission of news, exposure and 
opportunities heightens the perception of rising inequality and can lead to societal fragmentation, especially when there is inequality of opportunity or a mismatch between available jobs and skills. Overcoming this mismatch is a complex policy undertaking.

Second, technology is reshaping the skills needed for work. The demand for less advanced skills that can be replaced by technology is declining. At the same time, the demand for advanced cognitive skills, socio-behavioural skills, and combinations of skills associated with greater technological adaptability is rising. Over 94 per cent of global business leaders in 2020 reported that they expect employees to pick up new skills on the job - a sharp uptick from 65 per cent in 2018 (WEF, 2020). Already evident in developed countries, this pattern is starting to emerge in some developing countries (Lima et al., 2021 for Brazil). In countries where a large proportion of the workforce is poorly educated and low skilled, the ability to elevate adequate numbers to the appropriate skill levels remains limited, as is seen in the experiences and effectiveness of earlier skilling policies in India. More importantly, given that the new tasks are employing fewer people, simply having the skills may not suffice. Accelerated investment in upskilling and reskilling of workers is needed to keep/move people in technology-augmented jobs of tomorrow, and calls for concerted action by governments and by business to develop more inclusive and sustainable economies worldwide (WEF, 2021).

Third, technology can be disruptive, but the biggest concerns for workers are the socio-economic inequalities they feel most directly at work: un/underemployment, precarious employment, stagnant wages and poor social protection - further exacerbated by COVID-19. Pre-pandemic, 1.4 billion people worldwide were in "vulnerable forms of employment" in the informal sector, compared to 192 million unemployed; and 82 per cent of women in developing countries were in vulnerable forms of employment in 2017, compared to 72 per cent of men (ILO, 2018b). Structural inequalities of ethnicity, gender, religion, age and mobility reinforce the disadvantages in the labour market and at work. In many emerging and developing economies, a large number of workers perforce remain in low-productivity jobs, often in informal sector firms whose access to technology is poor.

These concerns around the impact of new technologies on the future of work - such as labour displacement, job polarisation, the transformational impact on employment, skills and equity - do not function in abstract. Rather, they are mediated through local social and economic relations and, therefore, need to be examined in specific societal and geographical contexts. The following section of this paper therefore considers the Indian context.

\section{Situating India: Informality, Jobless Growth and Inequality}


India displays most, though not all, features of a postcolonial, fast-growing emerging economy with some niche high-growth sectors, such as the IT sector and electronics. At the same time, high levels of poverty in agriculture, high levels of informality (comprising informal sector and informal employment), and industrial development rooted in informalisation, create a low-wage, lowproductivity, medium technology context for Indian capitalism. Social relations of gender, caste, ethnicity, and religion intersect with material relations, further reinforcing existing inequalities in the labour market and at the workplace (for a comprehensive review see Hammer, 2019).

The informal economy dominates, characterised almost universally by informal employment marked by subsistence wages and employment and social insecurity. Over 80 per cent of the Indian workforce is engaged in the informal sector, and about 92.4 per cent is in informal employment, a considerably higher share than the estimated 70 per cent average in other developing countries (NCEUS, 2009). Historically, agrarian reforms have failed to address social and economic inequalities, and industrial growth and urbanisation have also not translated into major formal employment gains. This has increased pressures on agriculture as well as the low-productivity non-agricultural informal sector to provide employment. As agriculture has been unable to sustain livelihoods, it created a situation of permanent labour surplus, with high levels of informality (largely subsistence self-employment/petty commodity production) inhibiting wage growth in the formal sector and preventing any escape from poverty and informality (Harriss-White, 2010). Agriculture remains the largest employer, with a vast majority (amounting to almost 60 per cent) depending on it directly or indirectly. These trends in agriculture and the informal economy were exacerbated after the liberalisation of 1991, and starkly after COVID-19, along with high and rising unemployment resulting in the recent migrant labour crisis (Hensman, 2020).

Furthermore, the growth in manufacturing in capital intensive high-technology industries, such as automobiles, has not translated into significant employment creation. A growth rate of 7 per cent has created less than 1 per cent employment growth, leading to fears of entrenched 'jobless growth' (Basole et al., 2018). Fewer than two million jobs are being created annually, in a country where the working age population grows by approximately 16 million every year. The rate of unemployment among youth, and the higher-educated in particular, is nearly twice that of any other category. at 16 per cent. Moreover, a majority of manufacturing firms are in the informal sector, with low wages, low productivity, and limited access to infrastructural support or credit (Raj and Sen, 2016). Jobless growth, rising unemployment and declining labour force participation in the manufacturing sector are accompanied by rising informalisation of the workforce, with a shift from permanent to temporary work, increasing de-unionisation among firms, and the decentralisation of bargaining, 
resulting in marginalisation of political unionism. The notable increase has been in contractual employment and self-employment, and the slowest growth has been in regular formal employment, suggesting a deterioration of employment conditions (Breman, 2010; Srivastava, 2015; Kapoor and Krishnapriya, 2017).

The disconnect between growth and employment has accompanied a shift towards service-led growth. The services sector contributed 63 per cent of GDP growth over the last decade, but a significantly smaller share in employment, at about 33 per cent. Though some niche areas have grown (such as the IT and BPO industries, retail and financial services), over 55 per cent of servicesector employment in India is still made up of petty trade, domestic services and other types of small-scale and informal employment, and - more recently - gig-activities by professionals, while the social sector services (education, health and public administration) account for 23 per cent of employment (Basole et al., 2018).

This sectoral skewness is compounded by the complex intersection of economic relations by social relations of gender, caste, and religion (among others) in the labour market and work and employment relations. India has one of the lowest labour participation rates for women, and this rate has been declining since 2004-05. Between 2011-2012, 19.6 million women dropped out of the workforce, of which 53 per cent were rural women. Participation rates among educated women are lower in urban areas, indicating a lack of meaningful work opportunities (Tandem report, 2018). Women and other marginalised groups are also more likely to be concentrated in subsistence selfemployment and the lowest rungs of employment, with restricted access to education and skills development, health and other public services; low levels of capital ownership; and greater discrimination while seeking employment or credit (NCEUS, 2009).

The education and skilling system reflects and reproduces the inequalities for the majority. Education is geared towards higher education, mostly accessible to the elite. Formal education and skill structures provided by the state suffer from poor quality, capacity and outcome. The most vulnerable segments of the workforce in the informal economy have poor access to institutions of training, accompanied by poor information dissemination and take-up - especially by disadvantaged groups - of government training initiatives launched in the last decade (NCEUS, 2009). The weakness of state provisioning has historically been accompanied by firms' reluctance to invest in training, since they prefer training casual labour on the job in order to keep labour costs low for a given skill set and to limit labour turnover (Breman, 2010). Only 17 per cent of firms in India provide in-service training, predominantly to formal workers, a minority in the labour force. According to the Periodic Labour Force Survey (2017-18), only 1.8 per cent of the population received formal vocational 
training, 5.6 per cent received informal training, while 93 per cent received no training. A purely supply-side approach could never counter the pervasive logic of capital accumulation based on informal labour and informal skilling (xxx, 2019). The Skill Certification and Reward Scheme and the Skill India Initiative, for youth training and employment, trained over 1.8 million individuals in 2015. However, only 12.4 per cent of the trainees were actually placed. On average, only 30 per cent of those skilled are highly skilled, and the rest have low or medium levels of skill (Tandem report, 2018).

This brief review underscores India's unique labour market conundrums: high degrees of informal work / self-employment, low productivity juxtaposed with the advent of mechanisation in the highgrowth sectors, low female participation in the workforce, and marginalisation of large groups. Job creation in the age of increasing automation is going to present severe challenges in a country already facing acute problems of high rates of formal unemployment, the 'skills problem', and poverty wages without any social security or employment protection. An assessment of the future of work, thus, needs to focus on: first, the role of surplus labour and of the vast informal economy. In a labour-abundant emerging economy like India, the rise of automation-induced-unemployment raises the spectre of potentially alarming consequences. Second, the impact of new technologies on employment is crucial in the context of a large informal economy, characterised by vast poverty and inequalities. Third, the extent and role of skilling and reskilling to meet the changing needs posed by automation and AI will be significant. According to NASCCOM, by 2022 around 46 per cent of the workforce of India will be engaged in entirely new jobs that do not exist today, or will be deployed in jobs that have radically changed skillsets. A recent survey (WEF, 2021) shows that 45 per cent of Indian companies accelerated their innovations and investments in Al during the pandemic, mostly in automating tasks that replace human labour and reconfigure traditional manufacturing value chain practices. However, skills development and deployment, so crucial to the adoption of new technologies, remains weak, inaccessible for the majority with limited scope for upskilling. Finally, the social impact of these new technologies, especially on the quality of work and societal equality, is critical. So far, work has reproduced social inequalities. The next section assesses the National Strategy on Al in the context of these concerns.

\section{National Strategy for Automation and Al and the Political Economy of Work and Employment in India}

The national strategy for automation and Al in India, articulated in the Government of India's 'National Strategy on Al' (NITI Aayog Discussion paper, 2018a, 2018b) and by top business and industry organisations, emphasises the high potential of automation and $\mathrm{Al}$, the importance of 
skilling to reap the benefits from these technologies, and their role in achieving inclusive development. This section outlines the key aspects of the strategy and assesses them against the political economy of work and employment in various sectors.

\section{The National Strategy for Automation and AI}

The strategy paper emphasises Al's economic impact and Al for greater good (social development and inclusive growth). Five sectors of the Indian economy are expected to benefit most significantly from Al and to achieve the goals of \#AlforAll: healthcare, agriculture, education, smart cities and infrastructure, and smart mobility and transportation. The paper identifies barriers that need to be addressed in order to achieve the goals of \#AlforAll: (a) lack of broad-based expertise in research and application of Al, (b) absence of enabling data ecosystems - access to intelligent data, (c) high resource cost and low awareness for adoption of $\mathrm{Al}$, (d) privacy and security, including a lack of formal regulations around anonymisation of data, and (e) absence of collaborative approach to adoption and application of Al.

According to the strategy, the barriers to Al development and deployment can effectively be addressed by adopting the marketplace model - one that enables market discovery of not only the price but also of different approaches that are best suited to achieve the desired results. A threepronged formal marketplace on a common platform called the National AI Marketplace (NAIM) is proposed, focusing on data collection, aggregation, annotation and deployable models. In its analysis and recommendations, the NITI Aayog paper emphasises the need for incentivising core and applied research on Al. It goes on to state that as technology increasingly disrupts the nature of jobs and shifts the benchmarks of technological aptitude, the skilling and reskilling of the existing workforce will be integral to adopting $\mathrm{Al}$, and for developing future talent in accordance with the changing needs of the job market. This is visualised via the adoption of decentralised teaching mechanisms, working in collaboration with the private sector and educational institutions to prescribe certification with value.

This approach to Al is supported by key industry organisations. The Federation of Indian Chambers of Commerce and Industry (FICCI), the oldest and largest apex body of business and industry, emphasises India's ongoing digital transformation and its lead in the global digital space. Through its focus on "Artificial Intelligence and Digital Transformation" FICCI forecasts that India's digital transformation market will reach $\$ 710.0$ billion by 2024 due to increasing adoption of emerging technologies under Industry 4.0 in the country. It engages its members for the overall growth of ICT adoption across sectors, and the major role played by Artificial Intelligence and Machine Learning (FICCI website, n.d.). The National Association of Software and Service Companies (NASSCOM), the 
top industry association for the IT and BPO industries in India, also reiterates the growing significance and impact of AI applications. NASSCOM is of high significance, since these trends relating to the future of work are closely associated with the IT and BPO industries. It sees global technology shifts as having laid the foundation for cutting edge innovation - with India emerging as a hub for innovative and transformational Al solutions and investments (2018 a, 2018b). More recent reports highlight that data science and Al could address the dual goals of economic and social value creation and recovery, with a potential to add $\$ 500$ billion to India's GDP by 2025 , support inclusive development, and contribute to COVID 19 responses and economic recovery. For NASSCOM, to harness the potential of Al requires the right mix of talent and technology to deliver value, especially in retail, agriculture, banking and healthcare. It estimates that about 40 per cent of the Indian technology workforce must be reskilled in the next 5 years to cope with new technologies, and workers may need to switch occupations (2020a, 2020b).

The national strategy is cognisant of the potential of new technologies and the role of skilling in adoption of these technologies. It focuses on job-creating sectors such as agriculture, health, education and urban infrastructure. Nevertheless, it suffers from a number of limitations, most critically in being technocratic and ignoring the historical and contemporary context of work and employment and accumulation processes. There are two glaring omissions. First, the challenges posed by the presence of a large informal economy and its centrality to the logic of capitalist accumulation in India, especially as the informal economy has long-standing and wide-ranging social implications. Second, while the critical role of skills in adopting new technologies is acknowledged, the plan of 'decentralised' teaching and training is not embedded in the reality of how skills are developed and deployed. The question then arises: will the advent of automation and Al break with and / or address these challenges in the Indian model of capitalism and work and employment relations? This is analysed in the following section with respect to work in key sectors.

\section{Informality and Precarity in Times of Al and Automation: A Sectoral Analysis}

This section assesses the potential and extent of adoption of new technologies in various sectors, and their impact on employment relations and labour market equality, to bring out the complexity of new technologies for the future of work.

\section{Manufacturing: Automation with Contractualisation and Self-employment}

The manufacturing sector has high automation potential, but the adoption of automation needs to be assessed alongside the trade-offs involved between the cost of technological upgrading and the cost of labour in India, a labour-abundant economy. Labour-intensive manufacturing industries, such 
as textile, apparel, leather and footwear, and paper manufacturers are unlikely to adopt high technologies because of their slow growth and need for high capital investments. In light of these factors, a significant barrier is the fact that a majority of these firms are small scale and in the informal sector. Even though certain work processes such as spinning are increasingly automated, firms are unlikely to transform their production processes because of the high costs associated with switching over and the abundant supply of low-cost labour. Capital intensive manufacturing industries, such as the high-technology export-oriented automobile and telecommunication production, are more likely to adopt advanced automation, partly because of the high number of routine tasks required for welding, polishing, and painting. Automation is increasingly used by automobile companies, which buy 60 per cent of all industrial robots sold in India, with 550 robots at work in the Ford plant, 400 at Hyundai, and another 4200 in the factories of Honda and Suzuki (Prakash, 2015). Indigenous firms such as Bharat Forge and other precision auto-component manufacturers also have highly automated plants.

With respect to work and employment, automation in the manufacturing sector is driven by contractualisation and labour replacement by firms. The share of contract workers in total employment rose from 15.7 per cent in 2000-2001 to 26.47 per cent in 2010-11, while that of directly employed workers fell from 61.12 per cent to 51.53 per cent in the same period. More significantly, the increase in contract workers has accounted for about 47 per cent of the total increase in employment in the organised manufacturing sector over the last decade (Hammer, 2019). It is fairly common in the industry for apprentices and contract workers to work alongside full-time workers to do the same job on the same shop floor, and for supply chains to source extensively from the informal economy (Hammer, 2010; Barnes, 2018). Thus, while new jobs may be created, increased contractualisation is leading to worsening of employment conditions. Contract workers can be easily dismissed, receive a much lower wage than permanent workers, and do not have access to social protection mechanisms. Firms also hire contract workers to reduce the bargaining power of regular, unionised workers (Srivastava, 2015).

Along with contractualisation, the other employment trend likely to intensify is a shift from wage employment to self-employment. While new opportunities for entrepreneurship may be created, evidence shows that, for most, self-employment is not a choice but a necessity. Over 80 per cent of the workforce in the informal sector is classified as self-employed, but operate at subsistence level with little access to capital or social security. Countering the myth that this shift to self-employment represents 'entrepreneurialism', the reality is of the 'hidden dependency' of self-employment, and its gendered and caste- and community-based basis, which is created through an intricate mechanism of subcontracting in global production networks. The self-employed are locked into 
unequal exchange relations with large firms or merchants, and depend on intermediaries for equipment and production inputs. The dependency is compounded by piece-rate payment schemes, which underpin work intensification and a reliance on self-exploitation and unpaid family labour. Though not labelled as formal wage labour, the self-employed are largely precarious, informal workers prone to very similar exploitative processes as formal wage workers, or worse (Hammer, 2019). Thus, a shift to self-employment with increased automation may signify increasing informality and precarity, and lower employment conditions for many.

\section{Services: Automation with Self-employment}

The impact of emerging technologies is most visible in the BPO and IT industries, the financial sector (particularly private sector banks adopting Robotic Process Automation technologies), and in customer services (with widespread use of chatbots and internet banking). Routine and back-end tasks are increasingly automated. However, this shift is likely to be technology driven and unlikely to create widespread employment opportunities, as suggested by a significant slowdown in hiring and an increase in redundancies in the IT sector since 2016-17. One report indicates that 640,000 lowskilled service jobs in the IT sector are at risk to automation, while only 160,000 mid- to high-skilled positions will be created in the IT and BPO service sectors (Tandem report, 2018). IT sector workers will need to rapidly upskill, but fewer jobs will be created in the medium-long run. Informalisation and contractualisation through outsourcing and subcontracting are increasing, at the cost of formal employment relationships. There is a growing preference for project-based teams and consultants as an alternative to full-time employees (Barnes, 2015).

The platform economy promises new economic opportunities for service workers, especially women and migrant workers, by enabling new forms of micro-entrepreneurship and freelance work. It can improve employment conditions in terms of higher income, better working conditions, flexible work hours, or access to banking. Platforms also promise a sense of community that can be mobilised for collective bargaining. However, leveraging these opportunities requires workers to have technical skills, when a majority have medium or low levels of skills and limited opportunity to upskill. The economic case for upskilling, particularly as India considers how best to allocate funding for the recovery from COVID-induced ravages, also highlights the disconnect between current education programmes and the skills that employers need. In terms of conditions of employment, surveillance and control belie the rhetoric of freedom, flexibility and autonomy. As argued by Graham et al. (2017), sharing labour platforms are unregulated, profit-seeking, data-generating infrastructures that rest on opaque labour supply chains and asymmetrical algorithmic operations. Like manufacturing, participation in gig-work is driven by the unavailability of alternative secure 
employment. Most workers work multiple jobs for multiple employers on a piece-rate basis, and lack access to formal social protection. Thus, automation is creating a flexible and controlled 'digital labour' base, reproducing informality and precarious working conditions rather than positively transforming work.

\section{Agriculture: Limited Automation and Persistent Poverty}

Agriculture remains the largest source of employment in India, and the national strategy rightly identifies agriculture as a major focus with a high automation potential. Most tasks can be classified as manual and routine, such as planting crops, applying pesticides and fertilisers, and harvesting. Applications of Al technology and data analytics also have the potential to improve farm productivity, highlighted by the many unicorn agri-tech start-ups in India. However, as in other sectors, the government neither makes reference to nor works to counter the underlying dynamics of agriculture and its role in creating and perpetuating informal employment.

Agriculture in India continues to be characterised by structural inequalities, widespread poverty, subsistence farming, low-skill levels and low productivity, as mentioned earlier. Ownership of land is concentrated amongst a few, with limited capital investment, while 75 per cent of rural workers work in the informal sector, and 85 per cent have no employment contract, health and safety or social security, some being subject to 'neo-bondage' (Breman, 2010; Harriss-White, 2010). In this context of high inequality combined with the decreasing size of land-holdings, low growth and low capital investment, any widespread adoption of advanced farm automation and digital technologies appears unrealistic. More likely is the adoption of micro-technologies and incremental mechanisation, rather than the large-scale adoption of advanced technologies. Growing labour surplus in agriculture continues to fuel the informal economy, where informal workers cannot break the vicious cycle of low wages and low skills, the absence of employment creation and increasing informalisation of formal manufacturing and service-sector jobs (in the platform economy and gigwork) are likely to aggravate these challenges.

\section{Skills as Panacea?}

To address the challenges and opportunities of Al and automation, skills have been identified as key in the national strategy. Yet, little attention is paid to the underlying social relations of production in which the practices of skills development occur, which is crucial for understanding the outcome of skills policies and practices (Streeck, 2011; Keep and Mayhew, 2010). Skilling and reskilling, which is so central to harnessing and managing the impact of new technologies, does not have a history of success in India. Key challenges remaining include poor education and skill structures, exclusion of 
vulnerable segments of the workforce in the informal economy, and firms' reluctance to invest in training and reliance of informal skilling.

Public sector investment in skilling initiatives in India is much lower than in developed countries such as Germany, which the state has tried to address through private-public-partnerships in the Industrial Training Institutes and industry-led vocational training programmes. Under its Skill India Mission, the government is engaged with technology firms and NASSCOM to solve job problems, to help close the skills gaps as in-demand skills across jobs change in the near term. NASSCOM's 'Future Skills' platform, which seeks initially to upskill 4 million IT employees and prospective job seekers in eight Indian states, is so far the only skilling ecosystem in India to be backed together by the IT industry, NASSCOM and the Indian government. It is aimed at driving a national skilling ecosystem for the emergent digital technologies.

There is a significant digital gender divide in terms of access to mobile technologies and the internet that adversely impacts skilling initiatives. In 2017, less than 30 per cent of India's Internet users were women. Women are also 23 per cent less likely than mento own a mobile phone, and only 14 per cent of women in rural India own a mobile phone (Tandem report, 2018). Women's access to digital technologies is likely to increase as the affordability and penetration of internet services and devices increases. However, low levels of literacy, education, and skilling, reinforced by societal norms, are likely to restrict the capacity of women as well as other socially disadvantaged groups to leverage new technologies.

Access to education and skilling is difficult and does not translate into employment opportunities. In this context, with the exception of a few highly skilled workers in the automotive and IT sectors, the inability of a majority of workers to access skills development initiatives and the lack of recognition of informally gained skills are likely to be persistent challenges to the up/reskilling that is so essential for the adoption of high technologies. It is difficult to see how this trend could be reversed, or why automated, digital firms will adapt to the change.

To answer the question posed earlier, existing evidence does not support a dramatic shift from the existing model of capitalism or a transformational impact of automation for workers; nor is it immediately conducive to embark on mass skilling drives. More likely is that the adoption of emerging technologies will be uneven and patchy. It may improve employment conditions for some individual workers, but will not alter employment conditions for the majority. There is largely a lack of public policy interventions needed to ensure that the emergent technologies are used responsibly to augment rather than replace labour, creating adverse distributional effects. What this means for the development models and social outcomes is discussed next. 


\section{Conclusions and Implications}

The critical assessment of automation and the future of work in India reveals that the national strategy of $\mathrm{Al}$ is not contextualised in the political economy of work, employment and skills development. In a mass informal economy context such as that of India, which has for long struggled to achieve broad-based performance (instead of the isolated pockets of excellence by which it has largely been characterised), the state strategy in its present form does not account for the deeprooted and enduring employment and skilling problems in India.

The sectoral assessment suggests that the adoption of high technologies will be in niche organised manufacturing and service sectors because of the relatively low cost of labour and infrastructural constraints. Capital intensive industries such as automobiles, and financial, legal and IT services have high automation potential. However, the overall impact on employment will be limited and skewed, as the majority of workers are employed in agriculture and the informal economy. In relation to employment, some opportunities will be created, but the spread of new technologies is likely to reproduce informal and precarious work rather than transform existing trends. Self-employment is likely to increase, but not necessarily accompanied by an improvement in employment conditions.

The societal implications of this uneven impact of automation on work are far reaching. Current trends suggest that technology-led disruptions to the future of work are likely to continue to exclude the vast majority of poor and predominantly low-skill workers, and to entrench labour market inequalities. The low cost of labour in the informal economy reduces the likelihood of technological adoption. A high incidence of poverty combined with low levels of education among semi-urban and rural men and women and marginalised social groups will limit their access to potential gains from technological development and restrict economic opportunities. Women and marginalised groups are even less likely to have the digital fluency skills and are more likely to occupy the low-medium skill level jobs that are most vulnerable to the effects of automation. In the IT and BPO sectors, for example, women tend to occupy low-skill, back-end jobs, which are likely to be automated first in terms of technical feasibility. Platforms do not yet provide access to social protections, thereby reproducing precarity. New technologies will also reinforce the vast urban-rural divide.

This is not to say that innovative opportunities for circumventing these barriers cannot be created through the adoption of new technologies - from the growth of the platform economy to remote learning opportunities - but their effectiveness will depend on how well they are integrated with broader policy interventions. The state has a significant role in shaping the conditions of work and in mediating capital and labour relations. It facilitates and perpetuates informal and precarious work through regulatory intervention (or lack of it) on the one hand, and provides poor and under- 
sourced skilling structures on the other. Both have critical implications for technological adoption and power relations at the workplace. At the same time, addressing both informal work and skills development is central to meeting the challenges posed by Al and automation. Automation and Al have the potential to address the complex challenges that India is facing across its demographic diversity, and in empowering the existing workforce. The state is central to this.

To conclude, the examination of the relationship between technology and the future of work in India shows that technology is not free from the wider dynamics operative in the world of work and is shaped by multiple forces. This suggests going beyond the current focus on the transformative or disruptive capacities of these technologies to a more balanced scholarship rooted in the reality of work (Thompson and Briken, 2017; Forde et al., 2017). This article is a first step in setting the context for much needed qualitative workplace studies that pay attention to how existing modes of production and social relations are being shaped by new technologies. Such studies will also help inform policymaking and skill development strategies in similar economies.

\section{References}

Arntz, M, Gregory, T and Zierahn, $U$ (2016). "The risk of automation for jobs in OECD countries: A comparative analysis", OECD Social, Employment and Migration Working Articles. Paris: OECD Publishing.

Autor, D H (2015). "Why Are There Still So Many Jobs? The History and Future of Workplace Automation", Journal of Economic Perspectives, 29(3):3-30, Summer.

Autor, D H and Dorn, D (2013). "The growth of low-skill service jobs and the polarization of the US labor market", American Economic Review, 103(5), 1553-1597. doi: 10.1257/aer.103.5.1553

Barnes, T (2015). The IT industry, employment and informality in India: Challenging the conventional narrative. The Economic and Labour Relations Review. 26(1):82-99.

Barnes, T (2018). Making Cars in the New India: Industry, Precarity and Informality. Cambridge University Press.

Basole A, Jayadev A, Shrivastava, and Abraham R (2018). State of Working India 2018, Azim Premji University. Download from: https://cse.azimpremjiuniversity.edu.in/state-ofworking-india/ (Accessed November 2019).

Boes, A. Kampf, T. Langes, B and Luhr, T (2017). 'The disruptive power of digital transformation', in Briken et al eds. The new digital workplace: how new technologies revolutionize work, Critical perspective on work and employment series, Palgrave, pages 153- 176. 
Braverman, H. (1974). Labour and Monopoly Capital, New York: Monthly Review.

Breman, J (2010). Outcast labour in Asia - circulation and informalisation of the workforce at the bottom of the economy, New Delhi: Oxford University Press.

Briken, K, Chillas, S, Krzywdzinski, M and Marks, A (2017). Labour process theory and the new digital workplace, in Briken et al eds. The new digital workplace: how new technologies revolutionize work, Critical perspective on work and employment series, Palgrave, pages 1-20.

Davala, S., Jhabvala, R., Mehta, S. and Standing, G. (2015) Basic Income. A Transformative Policy for India, London: Bloomsbury Academic.

De Stefano, V (2016). The rise of the "just-in-time" workforce: On-demand work, crowdwork and labour protection in the "gig-economy". ILO Conditions of Work and Employment Series (Vol. 7). Geneva: International Labour Office.

FICCl website, Al and Digital transformation, http://www.ficci.in/sector-details.asp?sectorid=127 (accessed 21 January 2021)

Ford, M (2015). Rise of the robots technology and the threat of a jobless future. New York: Basic Books.

Forde, C, Stuart, M, Joyce, S, Oliver, L, Valizade, D, Alberti, G, Hardy, K, Trappmann, V, Umney, C and Carson, C (2017) The Social Protection of Workers in the Platform Economy, European Parliament's Committee on Employment and Social Affairs, European Union.

Frey, C B and Osborne M A (2017). The future of employment: How susceptible are jobs to computerization?, Technological Forecasting and Social Change, 114: 254-280.

Fuchs, C (2016) 'Digital Labor and Imperialism', Monthly Review, 67(8): 14-24.

Goos, M, A Manning and A Salomons (2009). "Job polarization in Europe", American Economic Review, 99(2), 58-63.

Government of India (2016). Report on Fifth Annual Employment-Unemployment Survey 2015-16, September.

Graham, M., I. Hjorth and V. Lehdonvirta (2017) 'Digital Labour and Development: Impacts of Global Digital Labour Platforms and the Gig Economy on Worker Livelihoods', Transfer: European Review of Labour and Research, 23(2): 135-162. 
Hammer, A (2019) 'Comparative Capitalism and Emerging Economies: Formal-Informal Interlockages and implications for institutional analysis'. Review of International Political Economy, 26(2) 337-360.

Hammer, A (2010) 'Trade Unions in a Constrained Environment: Workers' Voices from a New Industrial Zone in India', Industrial Relations Journal, 41/2: 168-184.

Harriss-White, B (2010). Globalisation, the financial crisis and petty production in India's socially regulated informal economy. Global Labour Journal, 1 (1): 152-177.

Hensman, R (2020). The COVID-19 Lockdown in India: A Predictable Catastrophe for Informal Labour, Global Labour Journal, 2020, 11(3):320-324.

Hirschi, A (2017). “The Fourth Industrial Revolution: Issues and Implications for Career Research and Practice", The Career Development Quarterly, October.

International Labour Organization (2018 a). Women and Men in the Informal Economy: A Statistical Picture. Third edition. Geneva: ILO. http://www.ilo.org/wcmsp5/groups/public/dgreports/dcomm/documents/publication/wcms_626831.pdf [accessed May, 2020]. International Labour Organization (2018 b). "World Employment Social Outlook", Trends. Kapoor, R. and Krishnapriya, P. (2017). Informality in the Formal Sector: Evidence from Indian Manufacturing, International Growth Centre, Working Paper F-35316-INC-1, April.

Keep, E. and Mayhew, K. (2010). 'Moving beyond skills as a social and economic panacea', Work, Employment and Society, 24, 3, 565-577.

Lima, Y., Strauch, J.C.M., Esteves, M.G.P., de Souza, J.M., Chaves, M.B. and Gomes, D.T. (2021), Exploring the future impact of automation in Brazil, Employee Relations, Vol. ahead-of-print No. ahead-of-print. https://doi.org/10.1108/ER-08-2020-0364

McKinsey Global Institute (2016). Independent work: Choice, necessity, and the gig economy. McKinsey Global Institute (2017). Jobs Lost, Jobs Gained: Workforce Transitions in a Time of Automation, December.

Movitz, F. and Allvin, M. (2017) 'Changing systems, creating conflicts: IT-related changes in Swedish banking', in Briken, K et al. eds. (2017). The new digital workplace: how new technologies revolutionize work, Critical perspective on work and employment series, Palgrave, pages 132-152. 
NASSCOM REPORT (2018 a) Reinvent to Disrupt: Shaping a New Identity for the Indian IT Industry, https://nasscom.in/knowledge-center/publications/reinvent-disrupt-shaping-new-identity-indian-itindustry (accessed on 19 January 2021)

NASSCOM Report (2018 b) Top 50 Al Game Changers: Compendium of Best Al Solutions Use Cases https://nasscom.in/knowledge-center/publications/top-50-ai-game-changers-compendium-best-aisolutions-use-cases (accessed on 20 January 2021)

NASSCOM Report (2020 a) Unlocking Value from Data and AI - The India Opportunity https://nasscom.in/knowledge-center/publications/unlocking-value-data-and-ai-india-opportunity (accessed on 21 January 2021)

NASSCOM Report (2020 b) https://nasscom.in/knowledge-center/publications/unravelling-aihealthcare-india (accessed 21 January 2021)

National Commission for Enterprises in the Unorganised Sector (NCEUS) (2009). The Challenge of Employment in India: An Informal Economy Perspective, Report, New Delhi: Government of India.

NITI Aayog, Government of India (2018a) Report on National Strategy for Artificial Intelligence \#AlforAll,

NITI Aayog, Government of India (2018b). Strategy for New India @ 75, Government of India, November.

Prakash, A. (2015). "India's Asian Dilemma: How Best to Grow Robotics Industry?" Robotics Business Review, October 1, 2015.

Raj, SNR and Sen, K (2016). Out of the shadows? The informal sector in post-reform India, Oxford University Press: Delhi.

Schwab, K (2015). The Fourth Industrial Revolution: What It Means and How to Respond.

Srivastava, R. (2015) Structural Change and Non-Standard Forms of Employment in India, Conditions of Work and Employment Series No. 68 (Geneva: ILO), https://www.ilo.org/wcmsp5/groups/public/--ed_protect/---protrav/---travail/documents/publication/wcms_450077.pdf (accessed September 2018).

Standing, G. (2017) Basic Income: And How we Can Make it Happen, London: Penguin.

Streeck, W (2011). Skills and politics. General and specific, MPIfG discussion paper, No. 11/1 
Tandem Report on Emerging Technologies and the Future of Work in India (2018)

https://tandemresearch.org/assets/Tandem-FoW-Web-2018.pdf (accessed 3rd December 2020)

TeamLease Services Report (2018). 'Delhi leads gig economy, not Bengaluru: Report'.

Thompson, P. and Briken, K. (2017). Actually Existing Capitalism: Some Digital Delusions, In Briken et al (eds.) The new digital workplace: how new technologies revolutionize work, Critical perspective on work and employment series, Palgrave, p 241-263.

World Economic Forum (WEF 2020). "Future of Jobs Report 2020", October.

WEF (2021). "Upskilling for shared prosperity", report by the WEF and PWC Global, January.

World Bank (2018). World Development Report 2019: The Changing Nature of Work, Washington, DC: World Bank.

World Bank (2019). "Growing in the Shadow: Challenges of Informality", Chapter 3, Global Economic Prospects: Darkening skies, January, Washington, DC: World Bank.

\section{Author Biography}

Anita Hammer is a Senior Lecturer in Sociology of Work and Employment at Essex Business School, University of Essex, UK. Her research focuses on informal and precarious labour, social reproduction, automation and future of work, job quality, and workers' collective organisations. Anita has coedited the volume The Political economy of Work in the Global South: Reflections on Labour Process Theory (Red Globe Press, 2020); and guest edited (with Prof Immanuel Ness) a special issue on Informal and Precarious Work: Insights from the Global South, Journal of Labor and Society (forthcoming, 2021). Recent research has been published in Review of International and Political economy, International Journal of HRM, and Industrial Relations Journal. Anita serves on the editorial board of Work Employment and Society and Journal of Labor and Society. 